Studia z Dziejów Średniowiecza, t. 24, 2020

\author{
Adam Lubocki \\ (Uniwersytet Gdański, Muzeum Piśmiennictwa i Muzyki \\ Kaszubsko-Pomorskiej w Wejherowie) \\ https://orcid.org/0000-0003-2737-6043

\section{Bolesław Szczodry (1058-1079) konstruktorem środkowoeuropejskiego bloku antycesarskiego?}

https://doi.org/10.26881/sds.2020.24.04

Keywords: Bolesław Szczodry, Henryk IV, Central Europe, anti-German policy, eleventh century

\title{
Wprowadzenie
}

Czas rządów Bolesława Szczodrego to niewątpliwie okres wzrostu znaczenia Polski na arenie międzynarodowej. Wybitny monarcha poprzez umiejętnie prowadzoną politykę zagraniczną wyniósł swój kraj do rangi, którą wcześniej miał jedynie za Bolesława Chrobrego, pół wieku przed objęciem władzy przez Bolesława II. Druga połowa XI w. to również okres rodzącego się konfliktu między papiestwem a cesarstwem o prymat w świecie chrześcijaństwa zachodniego, który zaczą rysować się już od czasów ottońskich ${ }^{1}$, aczkolwiek dopiero Grzegorz VII określił wyraźnie i dobitnie postulaty i roszczenia Stolicy Apostolskiej względem cesarza i władców Europy Zachodniej²

Władca polski siłą rzeczy musiał w tym konflikcie opowiedzieć się za którąś ze stron. W powszechnej świadomości utarło się

1 A. Wielomski, Teokracja papieska 1073-1378. Myśl polityczna papieży, papalistów $i$ ich przeciwników, Warszawa 2011, s. 43-52.

2 Ibidem, s. 106-107. 
przekonanie, że bezwarunkowo popierał papieża, dzięki któremu miał rzekomo utrzymać niezależność od cesarstwa ${ }^{3}$. Szczegółowe badania prowadzone głównie przez Tadeusza Grudzińskiego pokazały jednak obraz zgoła odmienny. Bolesław jako wytrawny polityk miał świadomość, że uzyskanie poparcia władz kościelnych jest istotne, jednakże nie da militarnej przewagi nad Niemcami. W związku z tym usiłował stworzyć odpowiednio silny sojusz składajacy się z państw, które $\mathrm{z}$ różnych powodów cechował wrogi stosunek do Niemiec. Papież odgrywał tu również istotną rolę, niemniej jednak dla księcia polskiego ważniejsze były dobre relacje z sąsiadami, nawet kosztem sprzeciwienia się woli następcy św. Piotra, co zresztą prawdopodobnie miało miejsce. Czy jednak rzeczywiście chodziło o walkę z Henrykiem IV?

Problem ewentualnego montowania przez Bolesława Śmiałego szerszego sojuszu nadal jest zbyt słabo rozpoznany i nie spotkał się z należytym zainteresowaniem badaczy. Opracowania i rozprawy dotyczące Bolesława II koncentrują się głównie na trzech ostatnich latach jego panowania, a więc koronacji królewskiej, konflikcie z biskupem Stanisławem i ucieczką na Węgry ${ }^{4}$. Zdecydowanie najbardziej rozpalającym umysły badaczy watkiem jest tzw. sprawa św. Stanisława. Inne zagadnienia, takie jak np. polityka zagraniczna w początkowym okresie rządów (lata 60 . i początek 70 . XI w.) są natomiast bądź całkowicie pomijane, bądź traktowane skrótowo

3 Taki obraz widoczny jest m.in. w szerszych opracowaniach dziejów Polski lub też średniowiecza polskiego. Z obszernej literatury zob.: R. Grodecki, S. Zachorowski, J. Dąbrowski, Dzieje Polski średniowiecznej, t. 1: Do roku 1333, Kraków 2011, s. 134-135; K. Tymieniecki, Polska w średniowieczu, Warszawa 1961, s. 87; H. Samsonowicz, A. Wyczański, Historia Polski, t. 1: Polska do 1586, Warszawa 2007, s. 73; S. Szczur, Historia Polski. Średniowiecze, Kraków 2008, s. 110-111; M.K. Barański, Historia Polski średniowiecznej, Poznań 2012, s. 80-81; A. Zamoyski, Polska. Opowieść o dziejach niezwyktego narodu 966-2008, tłum. M. Ronikier, Kraków 2016, s. 18.

4 Trzeba tu wymienić takie dzieła, jak choćby: J. Umiński, W sprawie zatargu św. Stanisława z Bolesławem Szczodrym, PH 1947, t. 37, s. 138-152; K. Górski, O sprawie św. Stanistawa, NP 1948, t. 4, s. 61-81; R. Grodecki, Sprawa św. Stanistawa, Kraków 1979 [tekst ostatecznie powstał w 1953 r.]; Cz. Deptuła, Przyczyny upadku Bolestawa Śmiatego w świetle nowych badań, „Zeszyty Naukowe KUL” 1962, R. 5, s. 21-48; J. Powierski, Kryzys i upadek rzqdów Bolesława Śmiałego, Gdańsk 1992; T. Grudziński, Bolesław Śmiaty-Szczodry i biskup Stanisław. Dzieje konfliktu, Kraków 2010; D. Żerek, Zegnany. Biskup krakowski kontra król, Warszawa 2011; W. Bielak, Jeszcze w sprawie factum biskupa krakowskiego Stanistawa ze Szczepanowa, NP 2011, t. 115-116, s. 145-162. 
jako tło pewnych procesów. Do niedawna brakowało również wyczerpującej naukowej biografii tego władcy, a próby całościowego spojrzenia na okres jego panowania podjęte przez T. Grudzińskiego należy uznać za niewystarczające ${ }^{5}$. Dlatego też ciekawie w tym kontekście wypada wydana niedawno biografia Bolesława Śmiałego autorstwa młodego badacza Norberta Delestowicza ${ }^{6}$. Nie wychodzi ona jednak poza dzieje polityczne, co wbrew zapewnieniom widniejącym na tylnej stronie okładki nie czyni z niej pierwszej pełnej biografii tego władcy ${ }^{7}$. Ponadto budzi pewne kontrowersje, a głosy ją komentujące sa zarówno pozytywne, jak i negatywne.

Uważam zatem za konieczne bliższe przyjrzenie się zagadnieniom związanym z polityką zagraniczną Polski doby Bolesława Szczodrego, ze szczególnym uwzględnieniem jej antycesarskiego aspektu. Podjęcie w tym miejscu wszystkich kwestii jest niemożliwe, poza tym polityka wschodnia została już wystarczająco naświetlona przez Jana Powierskiego ${ }^{8}$. Również wzmianka o udziale Polaków w wyprawie Swena Estrydsena na Brytanię nie będzie - nie licząc drobnej wzmianki - obiektem mojej analizy, gdyż nie wnosi nic z perspektywy zakreślonego przeze mnie tematu ${ }^{9}$. Sama istota sporu z Henrykiem IV również została przedstawiona $\mathrm{w}$ literaturze przedmiotu ${ }^{10}$. Pewnych uzupełnień i uściśleń wymaga

5 T. Grudziński, Bolesław Szczodry. Zarys dziejów panowania, cz. 1, RTNT 1952 [druk: 1953], R. 57, z. 2. Praca ta w zasadzie skupia się wyłącznie na polityce zagranicznej i kontaktach Polski z państwami ościennymi. W tym zakresie jest to jednak dzieło bardzo wartościowe.

6 N. Delestowicz, Bolesław II Szczodry. Tragiczne losy wielkiego wojownika 1040/1042-2/3 IV 1081 albo 1082, Kraków 2016.

7 Autor sam przyznał we wstępie, że skupia się na polityce międzynarodowej, pomijając dzieje gospodarcze i społeczne, zob. ibidem, s. 11.

8 J. Powierski, Kryzys i upadek rzqdów... Tam dalsza literatura.

9 Ostatnio pisał o tym J. Szerle, Informacja o polskich positkach wojskowych $w$ morskiej wyprawie króla duńskiego Swena Estrydsena na Anglie w 1069 roku w „Historia Ecclesiastica” Orderyka Witalisa [w:] Wepoce żaglowców. Morze między antykiem a XVIII wiekiem, red. B. Możejko, Gdańsk 2016, s. 29-36. Tam dalsza literatura.

10 B. Schmeidler, Kaiser Heinrich IV. und seine Helfer im Investiturstreit. Stilkritische und Sachkritische Untersuchungen, Leipzig 1927, passim; E. Werner, Zwischen Canossa und Worms. Staat und Kirche 1077-1122, Berlin 1978, passim; J. Krasuski, Polska - Niemcy. Stosunki polityczne od zarania po czasy najnowsze, Warszawa 2009; T. Heller, Zwischen Vasallität Souveränität. Die wechselhaften Beziehungen des piastischen Polens mit dem Heiligen Römischen Reich in spezieller Berücksichtigung des Zeitraums 1058 bis 1138, München 2009; J. Sochacki, 
jedynie kwestia związków z sąsiadami południowymi (Węgry ${ }^{11}$, Czechy $^{12}$ ) i zachodnimi ${ }^{13}$ (Wieleci, Sasi).

Analizując proces montowania przez Bolesława II koalicji wymierzonej w Henryka IV, postaram się odpowiedzieć na pytanie, czy sojusze zawierane przez polskiego władcę wynikały jedynie

Stosunki publicznoprawne między państwem polskim a Cesarstwem Rzymskim w latach 963-1102, Wodzisław Śląski 2014, s. 118-157. Tam dalsza literatura.

11 Kwestia stosunków polsko-węgierskich nie spotkała się jak dotąd z należytym zainteresowaniem badaczy. Hermetyczność języka węgierskiego sprawia, że polscy badacze albo nie podejmują tej tematyki, albo podejmują ją w sposób błędny, wyciągając fragmentaryczne wnioski na podstawie nielicznych dostępnych dla nich prac. Dotyczy to niestety również takich koryfeuszy historiografii, jak Gerard Labuda czy Jerzy Dowiat. Więcej o tym zagadnieniu zob.: A. Lubocki, Trudności w badaniach kontaktów polsko-węierskich we wczesnym średniowieczu [w:] Badania i Rozwój Młodych Naukowców w Polsce. Nauki humanistyczne i społeczne, cz. 2: Historia i społeczeństwo, red. J. Nyćkowiak, W. Pryliński, Poznań 2019, s. 57-62. Nie powstała do tej pory wyczerpująca rozprawa prezentująca stosunki polsko-węgierskie we wczesnym średniowieczu. Do najcenniejszych prac ukazujących relacje polsko-węgierskie napisanych przez znawców tematyki polsko-węgierskiej należy zaliczyć: R. Grzesik, Polska Piastów $i$ Węry Arpadów we wzajemnej opinii (do 1320 roku), Warszawa 2003; idem, Obraz stosunków polsko-węierskich w czasach piastowskich w rocznikach polskich, SŹ, t. 41, 2003, s. 1-18; D. Bagi, Królowie wegierscy w Kronice Galla Anonima, Kraków 2008; S.A. Sroka, Wegry, Poznań 2015 (,Początki Państw”); idem, Divisio regni. Országmegosztás, trón viszály és dinasztikus történetírás az Árpádok, Piastok és Přemyslidák birodalmában a 11. és a korai 12. században [Divisio regni. Podział państwa, walka o tron i dziejopisarstwo dynastyczne w państwach Árpádów, Piastów i Przemyślidów w XI i na początku XII w.], Pécs 2017. Ważne są także prace dotyczące analizowanego okresu powstałe pod piórem takich badaczy, jak: O. Balzer, T. Grudziński, G. Labuda, K. Jasiński, J. Dowiat, zob.: T. Grudziński, Bolestaw Szczodry...; G. Labuda, Mieszko II król Polski (1025-1034). Czasy przełomu w dziejach państwa polskiego, Kraków 1992, s. 174-183; idem, Udziat ksiażat wegierskich w walkach polsko-pomorskich za Mieszka II czy za Kazimierza Odnowiciela? [w:] Opuscula minora in memoriam Iosepho Spors, red. J. Hauziński, Słupsk 1993, s. 65-76; K. Jasiński, Rodowód pierwszych Piastów, Kraków 1992, passim; J. Dowiat, Bela I wegierski w Polsce (1031/32-1048), PH 1965, t. 56, s. 1-23. Niewątpliwym mankamentem tych badaczy jest jednak nieznajomość języka węgierskiego, co przekłada się na brak węgierskiego punktu widzenia. Węgierski punkt widzenia - aczkolwiek również fragmentaryczny i obecnie nieco zdezaktualizowany - przedstawił M. Wertner, Az Árpádok családi története [Historia rodu Árpádów], Nagy Becskerek 1892, passim.

12 Stosunki polsko-czeskie co prawda doczekały się kilku pomniejszych opracowań, jednakże stanowisko historyków wobec polityki polskiego księcia jest oceniane niejednolicie i nie brakuje skrajnych opinii, w związku z czym należy przyjrzeć mu się nieco bliżej. Z literatury najciekawszy jest szkic G. Labudy, Zatargi z Czechami i Pomorzanami w pierwszym okresie rzadów Bolesława Śmiałego (1058-1073), ZH 1985, t. 50, z. 3, s. 33-45. Również cenne są ogólne prace poświęcone historii Czech czy też kontaktów polsko-czeskich.

13 O ile paradoksalnie związki polsko-saskie nie zostały należycie opisane, o tyle Wieletom T. Grudziński poświęcił osobną rozprawę, zob. T. Grudziński, Stosunki polsko-wieleckie $w$ drugiej połowie XI w., „Przegląd Zachodni”1952, z. 3-4. 
z chwilowej koniunktury, czy też stanowiły część większego planu związanego z próbą utworzenia szerokiego bloku państw prowadzących względnie jednolitą politykę i będących w stanie przeciwstawić się zakusom silniejszych sąsiadów, przede wszystkim Rzeszy. Wyciagnięcie takich wniosków będzie możliwe jedynie dzięki analizie wszystkich zawartych sojuszy na wspomnianym odcinku, ich okoliczności i ocenie ich trwałości.

Aby nie rozszerzać nadmiernie treści o teoretycznie niepowiązane wątki, kwestię ruską i skandynawską potraktuję skrótowo, odwołując się jedynie do najważniejszych zagadnień. Całościowa i gruntowna analiza polityki Bolesława Szczodrego wykracza znacznie poza ramy niniejszego artykułu, a szczegółowe rozważania odnośnie do relacji z Rusią mogą zaciemnić obraz domniemanej polityki antyniemieckiej polskiego władcy.

Być może pozwoli to spojrzeć na prowadzenie polityki we wczesnym średniowieczu pod nieco innym kątem niż zwykle. Często można spotkać się z poglądami, że działania władców - szczególnie we wczesnym średniowieczu - były pozbawione głębszej logiki i przemyślanych, konsekwentnie realizowanych długofalowych planów. To swoiste studium przypadku powinno wykazać, czy koncepcje te znajduja potwierdzenie w stosunku do władców powszechnie uznanych za utalentowanych polityków.

Aby tekst był bardziej przejrzysty, przyjałem w niniejszym artykule narrację mieszana, synchroniczno-diachroniczna. Wyodrębnię bowiem politykę polską względem każdego z państw i podzielę to na osobne zagadnienia, w ramach których przyjmę układ chronologiczny. Pozwoli to dostrzec ewolucję poglądów politycznych Bolesława Szczodrego w stosunku do wszystkich sasiadów, a jednocześnie umożliwi szczegółowe rozpatrzenie wszystkich związków z interesującymi mnie państwami ościennymi. Taki układ pracy spowoduje, niestety, drobne powtórzenia i odwoływanie się do tych samych wydarzeń w różnych partiach tekstu, niemniej jednak wydaje mi się on najwłaściwszy. Pominę przy tym niemal całkowicie rolę papieża Grzegorza VII, gdyż - podobnie jak T. Grudziński - sądzę, iż jego wpływ na działalność władców Europy Środkowej w świetle badań historyków zdaje się być umiarkowany ${ }^{14}$.

14 Więcej o polityce Grzegorza VII zob.: T. Grudziński, Polityka papieża Grzegorza VII wobec państw Europy Środkowej i Wschodniej (1073-1080), RTNT 1957 


\section{Węgry osią polityki Bolesława Szczodrego}

Stosunki polsko-węgierskie w wieku X i w pierwszej połowie XI nie należały do najlepszych. Źródła co prawda wspominają o czterech mariażach przedstawicieli dynastii Piastów i Árpádów, począwszy od czasów Mieszka ${ }^{15}$, ale dwa $\mathrm{z}$ nich to wydarzenia fikcyjne ${ }^{16}$, a dopiero małżeństwo zawarte w latach 30. lub 40. XI stulecia przez córkę Mieszka II miało wyraźniejsze odzwierciedlenie w polityce obu państw. Sytuacja międzynarodowa doprowadziła do tego, że oba państwa prowadziły bardzo zbieżną politykę, jak również miały wspólnego wroga, co siłą rzeczy wzmacniało sojusz. Co ciekawe i zastanawiające, dopiero rządy Bolesława Szczodrego i poprzedzający je schyłkowy okres panowania Kazimierza Odnowiciela przyniosły trwalszy sojusz polsko-węgierski i koordynowanie działań polityczno-militarnych ${ }^{17}$. Badacze węgierscy przesuwaja te wydarzenia na okres późniejszy ${ }^{18}$, sojusz Kolomana Uczonego i Bolesława III Krzywoustego, jednakże podwaliny pod to położyły już wydarzenia z lat 60. i 70. XI w.

[druk: 1959], R. 62, z. 1; W. Hartmann, Der Investiturstreit, München 2007; A. Wielomski, Teokracja papieska..., s. 101-176.

15 O. Balzer, Genealogia Piastów, Kraków 1895, passim; W. Felczak, A. Fischinger, Polska-Węgry. Tysiac lat przyjaźni, Warszawa-Budapeszt 1979, s. 11; S.A. Sroka, Węry..., passim.

16 W kolejności chronologicznej mowa tu o małżeństwach: 1. siostry Mieszka I z wielkim księciem węgierskim Géza; 2. Bolesława Chrobrego z nieznaną bliżej księżniczka węgierska; 3. węgierskiego królewicza Emeryka z Piastówna; 4. księcia Béli z córką Mieszka II. Pierwszy i trzeci mariaż został przez badaczy uznany za nieprawdopodobny i nie mający miejsca - Adelajda w świetle ostatnich badań jest postacią fikcyjną zmyśloną lub pomylona, a legenda świętokrzyska mówiąca o Emeryku to również późnośredniowieczna manipulacja stworzona na podstawie wcześniejszych - niemniej bałamutnych źródeł. Kwestią Adelajdy najszerzej w polskiej historiografii zajął się R. Grzesik. Do najważniejszych prac obalających mit Adelajdy należy zaliczyć: R. Grzesik, Adelajda, rzekoma księżniczka polska na tronie węgierskim [w:] Kobieta w kulturze średniowiecznej Europy. Prace ofiarowane Profesor Alicji Kartowskiej-Kamzowej, red. A. Gąsiorowski, Poznań 1995, s. 48-51; idem, Kronika wegiersko-polska. $Z$ dziejów polsko-węgierskich kontaktów kulturalnych w średniowieczu, Poznań 1999; K. Jasiński, Rodowód.... Kwestią Emeryka zajmował się M. Derwich, Polska legenda o świętym Emeryku, PH 1990, t. 81, z. 3-4, s. 423-446; idem, Benedyktyński klasztor św. Krzyża na Eysej Górze $w$ średniowieczu, Warszawa-Wrocław 1992, s. 238-260.

17 S.A. Sroka, Węrry..., s. 12; A. Lubocki, Od wygnańca do zięcia królewskiego, czyli udziat księcia węgierskiego Béli w walkach polsko-pomorskich [w:] Vade Nobiscum, t. 18, red. K. Banaś, P. Budzyński, P. Janicki, R. Stasiak, Łódź 2017, s. 175.

18 M. Font, Koloman the Learned, King of Hungary, tr. by M. Miklán, Szeged 2001, s. 63-77; D. Bagi, Królowie węgierscy..., s. 55. 
Postacia, która w dużej mierze za to odpowiadała po stronie węgierskiej, był książę - a potem od 1060 r. król Béla I - jeden z trzech męskich potomków księcia Vazula ${ }^{19}$ (Bazylego), bratanka wielkiego księcia Gézy. Zdaniem niektórych badaczy ojcem Béli był brat Vazula Władysław Łysy ${ }^{20}$, niemniej wydarzenia, które wówczas miały miejsce, świadczą raczej o ojcostwie Vazula. Kontrowersje te wynikaja zapewne $\mathrm{z}$ braku jednomyślności $\mathrm{w}$ tej kwestii w źródłach węgierskich ${ }^{21}$. Ten ostatni miał targnąć się na życie monarchy, dążąc do przejęcia władzy po śmierci Emeryka w 1031 r., w związku z tym Stefan I Święty kazał go oślepić, a jego synowie Andrzej (węg. Endre/András), Béla i Levente uciekli z Węgier do Czech, a później do Polski22. Istotne było także to, że synowie Vazula pozostali przy dawnych wierzeniach pogańskich $^{23}$. Andrzej i Levente wkrótce udali się na Ruś, a Béla pozostał w Polsce. Kroniki węgierskie wskazuja, że zaangażował się w walki toczone przez Polaków z Pomorzanami, a książę miał się odznaczyć męstwem, za które otrzymał za żonę córkę króla Mieszka II ${ }^{24}$. Niektórzy badacze uznają wiarygodność umieszczania tych wydarzeń w czasach syna Bolesława Chrobrego ${ }^{25}$, jednak większość przenosi

19 Imię to różnie się zapisuje w historiografii węgierskiej. Najczęściej spotykana jest forma zaczerpnięta bezpośrednio ze źródeł węgierskich - Vazul. Część badaczy uważa, że był to węgierski odpowiednik greckiego imienia Bazyli/Wasyl (węg. Vaszoly). Z obfitej literatury zob. m.in. L. Veszprémy, Vazul [w:] Korai magyar történeti lexikon (9-14. század) [Leksykon wczesnej historii Węgier (IX-XIV w.)], szerk. P. Engel, F. Makk (dalej: KTML), Budapest 1994, s. 721-722; F. Makk, I Béla [w:] KTML, s. 90.

20 Gy. Kristó, Magyarország története 895-1301 [Historia Węgier 895-1301], Budapest 2007, s. 113.

21 Przykładem może być kronikarstwo późnośredniowieczne stojące na stanowisku filiacji Władysława Łysego, wcześniejsze źródła podają natomiast Vazula. Najlepszym przykładem jest tutaj XIV-wieczna Kompozycja kronikarska, której autor wyraził wyraźnie wątpliwości w tej kwestii, uznając ostatecznie Władysława, zob. Chronici Hungarici compositio saeculi XIV (dalej: Kompozycja kronikarska) [w:] Scriptores rerum Hungaricarum tempore ducum regumque stirpis Arpadianae gestarum (dalej: SRH), vol. 1, ed. E. Szentpétery, Budapestini 1937, rozdz. 87, s. 344 .

22 Gy. Györffy, Święty Stefan I. Król Wegier i jego dzieło, tłum. T. Kapturkiewicz, Warszawa 2003, s. 449-452; A. Lubocki, Od wygnańca..., s. 169-170.

23 S.A. Sroka, Wegry..., s. 179.

24 Simonis de Kéza Gesta Hungarorum, ed. A. Domanovszky [w:] SRH, vol. 1, rozdz. 52, s. 177; Kompozycja kronikarska, rozdz. 78-79, s. 334-335.

25 M. Wertner, Az Árpádok..., s. 138; J. Dowiat, Bela I wegierski..., s. 1-23; K. Madeja, Kim byt ksiażę „Pomorza”, którego pokonat wegierski ksiażę Béla?, „Średniowiecze Polskie i Powszechne” 2019, t. 11 (15), s. 67-84. 
je na panowanie Kazimierza Odnowiciela ${ }^{26}$. Dokładna chronologia nie jest tu jednak istotna i nie ma większego wpływu na wydarzenia z lat 60. Istotny jest fakt, że książę węgierski pojął za żonę polska księżniczkę i miał z nią dwójkę dzieci, które najprawdopodobniej urodziły się w Polsce ${ }^{27}$.

W 1046 r. Andrzej zdecydował się na powrót na Węgry i walkę o władzę. Rozbił buntującego się przeciwko chrześcijaństwu Vatę (sam przyją chrzest, będąc na Rusi) i uspokoił zrewoltowany lud ${ }^{28}$. Sprowadził w 1048 r. do kraju swojego brata i nadał mu tzw. ducatus, stanowiący $1 / 3$ obszaru państwa obejmujący Nitrę i Bihar, a więc całą dzisiejszą Słowacczyznę i część Siedmiogrodu ${ }^{29}$. Béla był jedynym - nie licząc króla Andrzeja - żyjącym wówczas przedstawicielem dynastii Árpádów (Levente zmarł w czasie przejmowania władzy przez Andrzeja w 1047 r.), w związku z czym był naturalnym następcą monarchy, co też Andrzej oficjalnie zagwarantował ${ }^{30}$.

Zgoda i jedność między braćmi utrzymała się około dziesięciu lat. W tym czasie Węgry były zajęte wojną z Niemcami, usiłującymi odzyskać wpływy, które utraciły za rządów króla Piotra Orseolo. Złożył on hołd lenny cesarzowi, Andrzej natomiast

26 O. Balzer, Genealogia Piastów..., s. 167; B. Hóman, Geschichte des ungarisches Mittelalters, Bd. 1: Von den ältesten Zeiten bis zum Ende des XII. Jahrhunderts, Berlin 1940, s. 254-256; W. Dziewulski, W sprawie pobytu Beli I wegierskiego $w$ Polsce (uwagi krytyczne), PH 1966, t. 57, z. 2, s. 275; G. Labuda, Mieszko II..., Kraków 1992, s. 183; S.A. Sroka, Wegry..., s. 178-179.

27 Tak twierdzi Anonim zwany Gallem, jak również wspomniane kroniki węgierskie, zob.: Anonim tzw. Gall, Kronika polska, tłum. R. Grodecki, Wrocław-WarszawaKraków-Gdańsk-Łódź 1982, ks. 1, rozdz. 28, s. 50 („Ten Władysław od dzieciństwa chowany był w Polsce i pod względem obyczajów i [sposobu] życia niejako stał się Polakiem”); Kompozycja kronikarska, rozdz. 80, s. 335 (,Bela vero dux ipse in Polonia duos genuit filios, quorum unus Geysa, alter autem Ladizlaus nomineavi sui est vocatus").

28 Gy. Kristó, Megjegyzések az ún. „pogány lázadások” kora történetéhez [Uwagi dotyczące wczesnej historii tzw. buntów pogańskich], Szeged 1965, s. 43-48; S.A. Sroka, Historia Wegier do 1526 roku w zarysie, Bydgoszcz 2000, s. 25.

29 Ducatus był księstwem dzielnicowym, które otrzymywał następca tronu (syn lub brat/bracia panującego). Pełnił on podobną funkcję jak Morawy w księstwie czeskim od czasów testamentu Brzetysława I (o dzielnicach juniorów w Czechach zob. M. Matla, Czechy, Poznań 2014 [„Początki Państw”], s. 237-238). Po raz pierwszy ducatus pojawił się właśnie w czasach Andrzeja i przetrwał do czasów Kolomana Uczonego (I poł. XII w.), a więc funkcjonował z przerwami niecałe sto lat. Z obszernej literatury zob.: P. Engel, The Realm of St. Stephen. A History of Medieval Hungary, tr. by T. Pálosfalvi, London-New York 2005, s. 30-31; Gy. Györffy, Święty Stefan I..., s. 43-49; F. Makk, Hercegség [Księstwo] [w:] KTML, s. 261.

30 Z.J. Kosztolnyik, Five Eleventh Century Hungarian Kings: Their Policies and Their Relations with Rome, New York 1981, s. 74. 
próbował utrzymać niezależność od Rzeszy. Kryzys w braterskich relacjach spowodowały dopiero narodziny syna Andrzeja, Salomona (1052/1053), i oficjalne wyznaczenie go na następcę poprzez koronacje $(1057)^{31}$. Było to jawne zerwanie umowy z bratem, co rzecz jasna burzyło pewien ustalony porządek. Miało to na celu całkowite odsunięcie krewnych od władzy i rozprawienie się z żywa jeszcze wówczas zasadą senioratu, zakładająca dziedziczenie tronu przez najstarszego żyjącego przedstawiciela dynastii, nie zaś przez aktualnie będąca przy władzy linię ${ }^{32}$. Andrzej, będąc świadomym zagrożenia wojna domowa, postanowił przerwać wojnę z Niemcami. W 1058 r. zawarł oficjalny pokój, a gwarantem pokoju było małżeństwo Salomona z córką Henryka IV Judytą ${ }^{33}$.

Béla, zdając sobie sprawe z tego, że ma zbyt małe poparcie możnych i ludu, nie podjął walki i uciekł na przełomie 1059/1060 r. do Polski. Był to naturalny kierunek, gdyż tylko tam książę mógł szukać pomocy. Wynikało to z dwóch powodów: Bolesław był siostrzeńcem księcia, poza tym dążył do uniezależnienia swego państwa spod wpływów Rzeszy i dlatego szukał silnego sojusznika, zbliżanie się natomiast Andrzeja do Niemiec musiało budzić jego zaniepokojenie ${ }^{34}$. Władca Polski postanowił zatem wesprzeć swego krewniaka, zakładając, że Béla będzie prowadzić wspólnie z Polska politykę antyniemiecka. Jednak nie mógł zaangażować się osobiście w ten spór, dlatego postanowił wspomóc krewniaka, przekazując mu posiłki wojskowe, jak również szachując w tym czasie Czechów, uniemożliwiając ewentualną czeską pomoc dla Andrzeja ${ }^{35}$.

Wyprawa odwetowa Béli doszła do skutku jeszcze w $1060 \mathrm{r}$. W krótkim czasie zdobył znaczne poparcie Madziarów, a poplecznicy Andrzeja zaczęli go masowo opuszczać. W związku z tym król nie miał wielkich szans i nie tylko przegrał bitwę stoczona $\mathrm{z}$ bratem pod Weißenburgiem, ale także w jej trakcie poniósł śmierćc ${ }^{36}$. Młodociany Salomon zdołał uciec, aczkolwiek nie był w stanie

31 S.A. Sroka, Węgry..., s. 183.

32 Z. Dalewski, Modele władzy dynastycznej w Europie Środkowo-Wschodniej we wcześniejszym średniowieczu, Warszawa 2014, s. 255-256.

33 Ibidem; Z.J. Kosztolnyik, Five Eleventh Century Hungarian Kings..., s. 75.

34 N. Delestowicz, Bolestaw II Szczodry..., s. 25-26.

35 T. Grudziński, Bolesław Śmiały-Szczodry..., s. 17-18; N. Delestowicz, Bolestaw II Szczodry..., 31-51.

36 B. Hóman, Geschichte..., s. 268-269. 
powstrzymać Béli przed przejęciem władzy. Królowi nie pomogły nawet wojska Henryka IV, które go w tej walce wspierały ${ }^{37}$.

Salomon próbował skłonić Henryka IV do wyprawy na Węgry i przekazania mu władzy. Cel ten osiagną, kiedy obiecał całkowita wierność władcy niemieckiemu. Wielka armia ruszyła na Węgry w 1063 r. Na nic zdały się pojednawcze gesty Béli i obietnica zrzeczenia się tytułu królewskiego i zadowolenia się „ducatusem”38. Historycy nie dowierzaja jednak źródłom i twierdza, że była to próba gry na czasie ${ }^{39}$. Béla nie mógł się skutecznie bronić, gdyż wówczas był zmożony poważną choroba, z powodu której zmarł tuż przed wkroczeniem wojsk niemieckich ${ }^{40}$. Zmiana na tronie w takim momencie nie wpłynęła korzystnie na obronę granic, w związku z tym synowie Béli Géza i Władysław (László) ledwo uszli z życiem i udali się do Polski z prośbą o pomoc.

Wśród badaczy nie ma zgody co do powodów braku bezpośredniej pomocy ze strony Bolesława Szczodrego. Większość historyków motywuje to domniemanymi walkami na Pomorzu, które zaabsorbowały wszystkie siły polskiego władcy ${ }^{41}$. Wyprawa Henryka była jednak niezwykle szybka i doskonale zaplanowana, dlatego książę mógł nie mieć czasu na to, żeby wysłać wojska. Poza tym nie mógł formalnie skierować wojsk przeciwko królowi niemieckiemu. Ta koncepcja ma rację bytu jedynie wówczas, kiedy uznamy formalną zależność Polski od Niemiec, która miałaby się utrzymywać od czasów Bezpryma. Niektórzy badacze jednak uznaja, że nie miało to miejsca ${ }^{42}$. O ile zatargi z wasalami czy też sojusznikami seniora mogły ujść bez reperkusji, o tyle wyraźna obecność wojsk polskich w wojnie, w której Henryk brał bezpośredni udział - nawet

37 Kampanię tę relacjonują zarówno źródła niemieckie, jak i węgierskie, zob.: Lamperti Monachi Hersfeldensis Opera [w:] MGH SS, Bd. 38, ed. O. Holder-Egger, Hannoverae-Lipsiae 1894, s. 77-78, Anno D. 1061 [błędnie datowane przez rocznikarza]; Annales Altahenses Maiores, ed. W. von Giesebrecht, E.L.B. von Oefele [w:] MGH SS, Bd. 4, Hannoverae 1869, s. 56-57, An. 1060; Z.J. Kosztolnyik, Five Eleventh Century Hungarian Kings..., s. 76-77.

38 Annales Altahenses Maiores..., s. 62, pod rokiem 1063.

39 T. Grudziński, Bolestaw Szczodry..., s. 74-76; S.A. Sroka, Wegry..., s. $188-189$.

40 Z.J. Kosztolnyik, Five Eleventh Century Hungarian Kings..., s. 80.

41 T. Grudziński, Bolesław Śmiały-Szczodry..., s. 20.

42 K. Dróżdż, Kazimierz Odnowiciel. Polska w okresie upadku i odbudowy, Wodzisław Śląski 2009, s. 137-140. 
jeśli władca Polski nie dowodziłby osobiście - stanowiła jawne pogwałcenie prawa feudalnego.

Wydarzenia te można jednak interpretować nieco inaczej. Julia Tazbirowa uważa, że brak bezpośredniego zaangażowania Bolesława w 1063 r. mógł wynikać z tego, że nie zamierzał on włączać się zbyt mocno w sprawy węgierskie i pozostawić Gézę samemu sobie. Dowodem na to miał być rzekomo sojusz księcia polskiego z Wratysławem, jak również rozpaczliwa próba pojednania króla węgierskiego z władca Niemiec - uznana przez T. Grudzińskiego za element taktyczny i gre na czasie - będaca w rzeczywistości wyrazem osamotnienia politycznego Bélii ${ }^{43}$. Pogląd ten nie może się jednak utrzymać z tego względu, że władca polski wspomógł zbrojnie uciekających synów Béli, a brak informacji o udziale Wratysława w wyprawie Henryka, mimo że był on krewnym Salomona, świadczy na korzyść koncepcji stworzonej przez toruńskiego historyka. Świadczy to o tym, że zmiana negatywnego dla Polski stanu rzeczy była przez Bolesława Śmiałego pożądana, w związku z tym nie wahał się dać Gézie i Władysławowi zbrojnej pomocy. Tak twierdzi również Norbert Delestowicz $^{44}$. Bardziej prawdopodobna jest koncepcja Jarosława Sochackiego, opierająca się na ustaleniach Tadeusza Grudzińskiego ${ }^{45}$, zgodnie z którą Bolesław miał celowo zachować neutralność, która równała się z pozwoleniem na powrót Salomona na tron, aby zdezorientować Niemców i uniknąć bezpośredniej wojny z Rzesza ${ }^{46}$.

Henryk po osadzeniu na tronie Salomona wrócił do Rzeszy, a więc nowy monarcha musiał czuć się pewnie ${ }^{47}$. Bolesław zareagował natychmiast, co tym bardziej przeczy powyższym teoriom. Niecały miesiąc po przekroczeniu granicy polsko-węgierskiej przez uciekającego Gézę książę węgierski znowu ją przekraczał na czele wojsk polskich, dzięki którym miał odzyskać władzę. Rycerstwo węgierskie masowo go poparło i wszystko wskazywało na to, że Salomon po raz kolejny będzie musiał uciekać lub podzieli los ojca ${ }^{48}$. Tym razem historia się nie powtórzyła, gdyż w konflikt między kuzynami wtrącił się jako mediator biskup Dezyderiusz (węg. Dezsó).

43 J. Tazbirowa, [recenzja] T. Grudziński, „Bolesław Szczodry. Zarys dziejów panowania: część I”, PH 1954, t. 45/2-3, s. 514.

44 N. Delestowicz, Bolestaw II Szczodry..., s. 64-66.

45 T. Grudziński, Bolesław Szczodry..., s. 93.

46 J. Sochacki, Stosunki publicznoprawne..., s. 124.

47 Z.J. Kosztolnyik, Five Eleventh Century Hungarian Kings..., s. 80.

48 Ibidem, s. 81. 
W 1064 r. zawarte zostało zatem porozumienie w Győr ${ }^{49}$, w wyniku którego Salomon utrzymał swoją władzę królewska, nadając Gézie obszar, który jego ojciec nadał Béli I, a więc terytorium księstwa nitrzańskiego i Bihar (ducatus) ${ }^{50}$.

Tadeusz Grudziński, znawca rządów Bolesława Śmiałego, stwierdził, że ugoda ta nie zadowoliła żadnej ze stron i miała jedynie tymczasowy charakter ${ }^{51}$. Pogląd ten zdaje się jednak nie mieć potwierdzenia w rzeczywistości. Badacz spojrzał na to zagadnienie zbyt pobieżnie, co nie pozwoliło mu na dokładną i właściwą ocenę. Zgoda i ścisły sojusz dwóch przedstawicieli rodu Árpádów utrzymały się prawie dziesięć lat, co świadczy dobitnie o tym, że początkowo nikt nie zamierzał łamać ustalonego status quo. Co ważniejsze, Salomon i Géza podejmowali wszystkie akcje polityczne razem, a okres ten był czasem niebywałej aktywności państwa węgierskiego w zakresie polityki międzynarodowej i ekspansji. Dopiero osobiste urazy i rosnąca popularność bardzo energicznego Gézy wpłynęły na chęć usunięcia go ze sceny politycznej przez kuzyna ${ }^{52}$. To właśnie głównie ze względu na okres książęcy władca ten zasłużył potem na przydomek „Wielki” (Magnus) mimo zaledwie trzyletnich rządów (1074-1077).

Czarę goryczy przelała wojna z Bizancjum, a konkretniej zdobycie Belgradu w 1071 r. Grecki garnizon zdecydował się poddać nie królowi będącemu formalnym przywódcą wyprawy, lecz właśnie księciu, gdyż jak twierdzili, słynął on z łagodności i łaskawości względem przeciwników i wrogów. Salomon zemścił się za tę zniewagę, dając kuzynowi nie $1 / 3$, lecz jedynie $1 / 4$ wojennych łupów ${ }^{53}$. Po wyprawie greckiej postanowił pozbyć się rosnącego w siłę kuzyna. Géza jednak miał na dworze w Budzie popleczników,

49 W historiografii polskiej wydarzenie to nazywane jest układem raabskim, zob.: T. Grudziński, Bolestaw Szczodry..., s. 174-175; N. Delestowicz, Bolestaw II Szczodry..., s. 67. Nie jest to jednak precyzyjne, gdyż w rzeczywistości był on podpisany w Győr, a Rába (Raab to niemiecki wariant tego toponimu) to rzeka przepływająca przez to miasto. W historiografii węgierskiej dominuje pojęcie układu z Győr (györiegyezmény), zob.: Z.J. Kosztolnyik, Five Eleventh Century Hungarian Kings..., s. 81; F. Makk, Magyarkülpolitika (896-1196) [Węgierska polityka zagraniczna (896-1196)], Szeged 1996, s. 98.

50 S.A. Sroka, Wegry..., s. 81-82.

51 T. Grudziński, Bolesław Śmiaty..., s. 20, 29.

52 Okres współpracy i późniejszy konflikt dość szczegółowo został omówiony w Kompozycji kronikarskiej, rozdz. 97-123, s. 361-394. Więcej o współdziałaniu obu władców zob.: Z.J. Kosztolnyik, Five Eleventh Century Hungarian Kings..., s. 82-84; S.A. Sroka, Węrry..., s. 191-193.

53 S.A. Sroka, Wegry..., s. 193-194. 
którzy natychmiast donieśli mu o planach króla. Książę - zdaniem autora Roczników hersfeldzkich - zareagował od razu i to prawdopodobnie on rozpoczął wojnę z Salomonem ${ }^{54}$. Tradycja węgierska zachowała jednak obraz przeciwny. To Salomon miał zaatakować Gézę i początkowo odnieść pewne sukcesy, jednakże w wyniku zdrady możnych i rycerstwa poniósł ostatecznie klęskę ${ }^{55}$. Nie jest istotne, kto rozpoczął spór, lecz to, że zakończył się błyskawicznie i Salomon po raz kolejny musiał uciekać.

Nie był to jednak koniec rywalizacji pomiędzy stryjecznymi braćmi. Weszła w zupełnie inną fazę, gdyż od tej pory to Géza był stroną dominujacca, a Salomon wygnańcem usilnie próbujacym za wszelką cenę powrotu na tron. Nie miał już nic do stracenia, zatem z jego perspektywy złożenie hołdu wydaje się naturalne. Dopiero ten krok skłonił Henryka do podjęcia wyprawy zbrojnej na Węgry ${ }^{56}$. Jednakże mimo osobistego udziału w wyprawie nie udało mu się niczego osiagnacć, głównie ze względu na zastosowana przez króla węgierskiego taktykę spalonej ziemi. Géza cały czas wycofywał się przed wchodząca w głąb Węgier armia niemiecka, niszcząc przy tym wszystkie zapasy żywności i przesiedlając miejscową ludność na bezpieczniejsze terytoria. Dzięki temu Niemcy pozbawieni dostaw żywności szybko zaczęli odczuwać głód. To w głównej mierze skłoniło Henryka IV do rokowań i wycofania swoich wojsk ${ }^{57}$. Od tej pory nie angażował się w spory wewnętrzne na Węgrzech, gdyż zajął się sprawami włoskimi i wewnętrznymi problemami w Rzeszy, m.in. ostatecznym rozbiciem rebelii saskiej. W dalszym ciagu Salomon przebywał na pograniczu i wypatrywał sprzyjającej okazji, nie stanowił jednak realnego zagrożenia, gdyż nikt $\mathrm{z}$ elit go nie popierał. W związku z tym bez pomocy z zewnątrz nie miał szans na jakąkolwiek próbę zmiany sytuacji.

W kwestii sojuszu z Węgrami istotny jest także stosunek papieża Grzegorza VII do Gézy i Salomona. Niektórzy badacze - z Tadeuszem Grudzińskim na czele - uważaja, że to głównie dzięki wpływom Bolesława Śmiałego i jego kontaktom z Kurią udało się Gézie utrzymać władzę i sprawić, że papież przestał naciskać, by król węgierski

54 Lamperti Monachi Hersfeldensis Opera..., s. 195, pod rokiem 1074: „[...] Salomon rexUngariorum a Ioiade [tj. Gézę] Beli filio belloimpetitus et tribus iampreliisvictus, amissoexercitu, vix de regnoeffugisset”.

55 Simonis de Kéza Gesta Hungarorum..., c. 60, s. 180-181.

56 Z.J. Kosztolnyik, Five Eleventh Century Hungarian Kings..., s. 88.

57 S.A. Sroka, Wegry..., s. 196-197. 
zwrócił władzę Salomonowi ${ }^{58}$. Co prawda nigdy nie zwrócił się do Gézy tytułem królewskim, nazywając go zawsze księciem, jednak mimo to, posiadając moralne wsparcie polskiego księcia, mógł się oprzeć papieskiej presji ${ }^{59}$. Następca na tronie węgierskim, brat zmarłego króla, Władysław, znalazł już poparcie u Grzegorza VII ${ }^{60}$. Nie wiadomo, czy rzeczywiście polski władca odegrał tu jakąkolwiek rolę, jednakże można przypuszczać, że rzeczywiście mamy do czynienia z pewnymi naciskami na papieża ze strony polskiej, a jeśli nie naciskami to przynajmniej szczegółowymi informacjami o sytuacji politycznej w Europie Środkowej i podstawami konfliktu między Salomonem a Géza. Nie ma jednak na to dowodów i koncepcja ta pozostaje hipotezą bez żadnej mocy dowodowej. Jedyną przesłankę pośrednią może stanowić wzmianka Anonima Galla o wpływie polskiego księcia na obsadzenie Władysława na tronie węgierskim ${ }^{61}$, jak również rzekomy wpływ na obsadę tronu węgierskiego widoczny w Kronice wegiersko-polskiej ${ }^{62}$. We wspomnianym źródle nie znajdujemy żadnej wzmianki o roli papieża.

Tak pokrótce przedstawiała się polityka Bolesława Szczodrego względem Węgier. Jak można zauważyć, starał się za wszelka cenę utrzymać przy władzy przychylnych mu władców, czy to w osobie swego wuja Béli, czy też kuzyna Gézy. Popierając krewnych, wspierał jednocześnie tzw. obóz narodowy, a więc przeciwników wpływów niemieckich. Nie zawsze mógł bezpośrednio wpływać na wynik walk wewnętrznych, gdyż był zajęty działaniami w innych rejonach. W połowie lat 70. jednak wyraźnie przejał rolę przywódcy, m.in. w trakcie negocjacji z papieżem Grzegorzem VII, dążąc do uzyskania papieskiej akceptacji

$58 \quad$ T. Grudziński, Polityka papieża..., s. 46;

59 Ibidem, s. 46.

60 M. Łodyński, Wegry lennem Stolicy Apostolskiej, KH 1910, t. 24, z. 1, s. 63.

61 Anonim tzw. Gall, Kronika polska..., rozdz. 27, s. 50.

${ }^{62}$ Zdaniem autora tej kroniki książę Polski Bolesław miał bezpośredni wpływ na obsadę tronu węgierskiego i decydował niejako o tym, który z książąt ma przejać władzę. Imiona Árpádów są co prawda pomieszane, a kronika jako dzieło historyczne nie cieszy się zaufaniem badaczy, może to być jednak delikatny ślad pamięci o wpływach Bolesława Szczodrego. Ze względu na niską wartość wspomnianego źródła, należy jednak podchodzić do tego ostrożnie. Udział polskiego władcy został opisany w Kronice węiersko-polskiej, zob. Chronicon Hungarico-Polonicum, ed. J. Deér [w:] SRH, vol. 2, Budapestini 1938, rozdz. 13, s. 318-320. Polskie tłumaczenie: Żywot św. Stefana króla Węier, czyli kronika wegiersko-polska, tłum. R. Grzesik, Warszawa 2003, s. 98-103. 
dla rządów Gézy. To wszystko miało na celu stworzenie silnego sojuszu, który byłby w stanie przeciwstawić się Niemcom i ich roszczeniom względem Polski i Węgier.

Szacunek do władcy polskiego i roli, jaką odegrał w dziejach Węgier tego okresu, podkreślają zgodnie zarówno kroniki polskie (Anonim zwany Gallem ${ }^{63}$, Wincenty Kadłubek ${ }^{64}$ ), jak i węgierskie (m.in. Kronika węgiersko-polska) ${ }^{65}$. Tak więc wpływ Bolesława Szczodrego na obsadę węgierskiego tronu nie powinien być podawany w wątpliwość. Wiele wskazuje na to, że sojusz polsko-węgierski był w tym czasie osia polityki zagranicznej zarówno dla władcy polskiego, jak i walczacych z Salomonem synów Béli I. Wynikało to jednak w głównej mierze ze zbieżnych interesów politycznych i wspólnego wroga zewnętrznego, którym była Rzesza. Zapewne głównie ten aspekt decydował o trwałości sojuszu. Warto przy tym zwrócić uwagę na fakt, że już pół wieku później Węgry na długi czas znalazły się w przeciwnym obozie. Do momentu, kiedy królowie węgierscy pozostawali w konflikcie z Cesarstwem, sojusz z Polska był korzystny i potrzebny. Jednak w chwili śmierci Kolomana Uczonego jego następcy zbliżyli się do Czech i Niemiec. Widać więc wyraźnie, że głównym czynnikiem łączącym Polskę i Węgry we wczesnym średniowieczu był wrogi stosunek do zdecydowanie silniejszego zachodniego sąiada, którego można było pokonać jedynie dzięki ścisłemu współdziałaniu.

\section{Sasi i Wieleci - bezprecedensowa próba pojednania obu ludów?}

\section{Sojusz sasko-wielecki i domniemana polska inicjatywa}

Niezwykle ciekawie w kontekście polityki zagranicznej Bolesława wygląda kwestia sojuszu rzekomo zawiąanego z Wieletami $^{66}$ i Sasami. Kwestia ta stanowi sytuację bezprecedensowa.

63 Anonim tzw. Gall, Kronika polska..., rozdz. 27, s. 50.

64 Magistri Vincentii Chronica Polonorum, wyd. M. Plezia [w:] MPH s.n., t. 11, Kraków 1994, ks. II, rozdz. 18.

65 Chronicon Hungarico-Polonicum..., rozdz. 13, s. 318-320.

66 Termin Wieleci, Zwiazek Wielecki jest co prawda w odniesieniu do drugiej połowy XI w. niespotykanym już w źródłach anachronizmem, niemniej jednak stosuję 
Szczególnie zaskakujace jest prawdopodobne nawiązanie przyjaznych stosunków pomiędzy Słowianami i przedstawicielami największego niemieckiego księstwa szczepowego. Przyjmuje się niekiedy, że to właśnie dzięki działalności mediacyjnej księcia polskiego Sasi zaprzestali najazdów na terytorium Połabia, Wieleci natomiast odmówili udziału w jakichkolwiek wrogich działaniach przeciwko Sasom ${ }^{67}$. Nie znajduje to żadnego bezpośredniego potwierdzenia w źródłach i stanowi jedynie niezwykle misterna kombinację badawcza. Aby dobrze zrozumieć problem - a w efekcie dać jasna odpowiedź na pytanie, czy działo się to z inicjatywy polskiego władcy - należy się przyjrzeć stosunkom sasko-wieleckim w tym okresie, gdyż dopiero całkowity obraz tej złożonej sytuacji pozwoli dostrzec motywy i uwarunkowania obu stron.

Wiele wskazywało na to, że Związek Lucicki przestanie istnieć już w latach 70. XI w. i zostanie podbity przez germańskich sasiadów. Przewaga Sasów była wówczas tak duża, że Słowianie okazali się niemal bezsilni i nie byli w stanie przeciwstawić się niszczącym najazdom niemieckim. Co prawda w 1056 r. pokonali znaczne oddziały saskie w bitwie pod Przecławą ${ }^{68}$, niemniej jednak potem (1057) wybuchły walki wewnętrzne, w wyniku których Czrezpienianie i Chyżanie odłączyli się od Związku i zostali podporządkowani przez księcia Obodrzyców Gotszalka ${ }^{69}$.

Najdotkliwsza okazała się jednak seria kilku saskich wypraw wojennych na Wieletów z lat 1067-1069, kiedy to zostały spustoszone znaczne połacie państewek pozostałych w Związku, a zdaniem Adama z Bremy miała ucierpieć także stolica Redarów, Radogoszcz ${ }^{70}$. Był to z pewnością wielki cios dla dumnych

go w niniejszym artykule zamiennie z określeniem Lucicy. Podobnie zresztą czyni znaczna część współczesnych badaczy, zob. G. Labuda, Wieleci [w:] SSS t. 6,s. 430-431. Obu nazw używał również m.in. piszący w połowie XII w. Helmold, zob. Helmolda Kronika Stowian, tłum. J. Matuszewski, Warszawa 1974, passim.

67 Tak m.in. T. Grudziński.

68 J. Widajewicz, Niemcy wobec Stowian połabskich, Poznań 1946, s. 25-26; J. Strzelczyk, Stowianie połabscy, Poznań 2013, s. 72; R.F. Barkowski, Stowianie połabscy. Dzieje zagtady, Warszawa 2015, s. 187-188.

69 J. Strzelczyk, Stowianie połabscy..., s. 72-73; R.F. Barkowski, Stowianie połabscy..., s. 188-189; W. Kowalenko, Gotszalk [w:] SSS, t. 2, s. 143; A. Wędzki, Gotszalk [w:] Maty stownik kultury dawnych Stowian, red. L. Leciejewicz, Warszawa 1972, s. 125.

70 Annales Augustiani, ed. G.H. Pertz, MGH SRG, Bd. 5, Hannoverae 1839, s. 128, pod rokiem 1068: „Burchardus Halberstatensis episcopus, Luiticiorum provintiam ingresssus, incendit, vastavit, avec toque equo, quem pro Deo in Rheda colebant, super eum sedens in Saxoniam rediit". Wspomina o tym także Adam z Bremy, 
Słowian i dowód na niemal całkowity upadek znaczenia Wieletów. Kolejne wyprawy mogłyby bez problemu po raz kolejny sięgnąć serca Związku i całkowicie zniszczyć święte miasto Słowian połabskich, a co za tym idzie - doprowadzić do ostatecznego upadku ostatnich niezależnych pogańskich państw plemiennych nad południowym Bałtykiem ${ }^{71}$.

W latach 70. XI w. działania wojenne nagle zanikły i żadna ze stron konfliktu nie wykazywała woli dalszej walki. Powszechnie się uważa, że w wypadku Sasów wynikało to z początków działalności antykrólewskiej. Rozdźwięk wśród badaczy budza natomiast motywy Słowian. Zaangażowanie ich odwiecznych wrogów na innym froncie stanowiło doskonałą okazję do pomsty i odzyskania przynajmniej części strat. Tymczasem źródła nie wspominają o jakiejkolwiek aktywności Wieletów, wręcz przeciwnie. Większość historyków przypisuje to nadmiernemu wyczerpaniu Słowian, spowodowanym ciagłymi wojnami i dotkliwym złupieniem ich terytoriów ${ }^{72}$. Józef Widajewicz stwierdził wręcz, że „tymczasem niepojęta apatia ogarnęła jego [Związku Wieleckiego - A.L.] członków"73.

Zupełnie inne stanowisko w tej kwestii przyją T. Grudziński. Uważał bowiem, że przełomowym, jeśli chodzi o stosunki polsko-wieleckie, był rok 1069 i słynna wyprawa króla duńskiego Swena Estrydsena na Wyspy Brytyjskie i królestwo Anglii. Wówczas mogło dojść do spotkania wojsk polskich i wieleckich, co zaowocowało nawiązaniem wzajemnych relacji ${ }^{74}$. Ciężko jednak się z tym zgodzić, gdyż taka wyprawa wojenna nie była najlepszym sposobem do nawiązywania kontaktów politycznych. Nie jest zresztą pewne, czy rzeczywiście Polacy wzięli w niej udział, a jeśli nawet, to zapewne byli to wojownicy z podległego Polsce Pomorza Gdańskiego, gdyż

zob. Magistri Adam Bremensis Gesta Hammaburgensis Ecclesiae Pontificum, ed. B. Schmeider, MGH SRG, Bd. 2, Hannoverae-Lipsiae 1917, lib. 3, cap. 21, s. 165-166.

71 Co prawda na tym obszarze istniały jeszcze wówczas państwa pogańskie, jednakże Stodoranie nie odgrywali wówczas większej roli, a Obodrzyce nie byli do końca zdecydowani, czy wybrać chrześcijaństwo, czy też pozostać przy pogaństwie. Poza tym ci ostatni formalnie byli zależni od Sasów, w związku z tym książęta obodrzyccy nie prowadzili całkowicie samodzielnej polityki, zob. R.F. Barkowski, Stowianie połabscy..., s. 190.

72 J. Widajewicz, Niemcy wobec..., s. 28; J. Strzelczyk, Stowianie połabscy..., s. $74-75$.

73 J. Widajewicz, Niemcy wobec..., s. 28.

74 T. Grudziński, Bolesław Śmiały-Szczodry..., s. 28. 
jedynie oni dysponowali okrętami i wiedzą z zakresu żeglugi morskiej. Poza tym w wyprawie tej wzięli udział zwykli wojowie, nie zaś dostojnicy mający wpływ na politykę państwa. Bolesław zdecydowanie więcej mógł osiagnaćc, wysyłając bezpośrednie poselstwo do Radogoszczy, co też najprawdopodobniej uczynił.

Sądzę, że wzmianka, która wywołała tyle zamętu w polskiej historiografii, jest warta przytoczenia, gdyż sama w sobie wnosi kilka istotnych informacji. Ordryk Witalis w dziele Historia Ecclesiastica zapisał: „Ten [Swen Estrydsen - A.L.] rozporządzał wielka potęga, ściagał wszystkie siły ze swego królestwa, do których dołączył wielkie posiłki z sassiednich i zaprzyjaźnionych krajów. Wspomagali go: Polska, Fryzja, tudzież Saksonia. Także Lucicy na wyprawę angielska przysłali oddziały posiłkowe"75.

Jak widać, chodzi tu nie tylko o sprzymierzeńców, ale także sasiadów (również zamorskich). Ponadto ostatnie badania wykazały, że posiłki wzmiankowane przez Ordryka Witalisa były w zasadzie zbieraniną luźnych oddziałów najemnych, nie zaś zorganizowanymi kontyngentami sojuszniczymi. Poza tym jest co najmniej watpliwe, że Bolesław, czy choćby podlegli mu Pomorzanie, rzeczywiście wzięli udział w tej wojnie ${ }^{76}$. Dlatego też należy szukać innej sposobności do prawdopodobnego nawiązania dwu-, a potem także trójstronnych kontaktów.

Mogła nią być z kolei osoba księcia obodrzyckiego Gotszalka, prawdopodobnie spokrewnionego ze Swenem II Estrydsenem. Adam Bremeński podał jedynie informację o poślubieniu przez księcia królewny duńskiej ${ }^{77}$, bazujący na nim Helmold wskazał natomiast Kanuta Wielkiego jako jej ojca ${ }^{78}$. Saxo Grammatyk twierdził jednak, że była to córka właśnie Swena II. Gdyby tak rzeczywiście było, to mielibyśmy ważną poszlakę w poszukiwaniu ewentualnego śladu współpracy połabsko-skandynawsko-polskiej z czasów Bolesława Szczodrego.

Jest faktem, że od 1070 r. wyprawy saskie nagle się urywaja. Wspomniany już T. Grudziński twierdził, że mediatorem był tutaj właśnie władca polski. Nie można jednak doszukiwać się w wyprawie wojennej skandynawskiego króla płaszczyzny ewentualnego porozumienia.

75 Tłum. J. Szerle, cyt. za J. Szerle, Informacja o polskich positkach wojskowych..., s. 29.

76 Ibidem, s. 35-36.

77 Magistri Adam Bremensis..., lib. 3, cap. 19, s. 162.

78 Helmolda Kronika Stowian..., ks. 1, rozdz. 19, s. 146. 
Z cała pewnością książę polski utrzymywał kontakty zarówno z Radogoszczą jako sąsiadami państwa polskiego, jak i z elitą saską na długo przed rokiem 1069. Możliwe, że dopiero eskalacja konfliktu z Henrykiem IV - widoczna między innymi w otwartym poparciu dla antyniemieckich władców Węgier oraz w negatywnym stosunku imperatora do stałych walk na pograniczu polsko-czeskim - skłoniła Bolesława Śmiałego do bardziej stanowczych działań. Również istotne było narastanie opozycyjnych nastrojów w Saksonii.

Wbrew twierdzeniom T. Grudzińskiego nie ma jednak żadnych przesłanek, które pozwalałyby na twierdzenie, że w 1070 r. został zawiązany sojusz sasko-wielecki ${ }^{79}$. Historyk ten oparł swoje wywody na kilku zasadniczych argumentach. Pierwszym z nich jest obietnica, jaką Swen Estrydsen miał złożyć Henrykowi IV. Zobowiązał się - w zamian za uzyskanie obszarów na pograniczu sasko-duńskim - do udzielenia pomocy władcy niemieckiemu w walce z każdym jego wrogiem, szczególności z Sasami. To sformułowanie T. Grudziński odnosi do Wieletów, gdyż twierdzi, że na tym obszarze jedynie oni mogli być wrogami Danii ${ }^{80}$. Nie można jednak tej formuły rozumieć konkretnie, gdyż bardzo często była stosowana przez dwóch władców zawierających sojusz. Zazwyczaj nie chciano zawierać koalicji przeciwko jednemu konkretnemu wrogowi, natomiast swoistym wyjściem w tej sytuacji była właśnie formuła „przeciwko wszystkim wrogom" $"$.

Kolejnym argumentem ma być poselstwo Henryka IV do Wieletów, które dotarło do Radogoszczy w przeddzień rozprawy Henryka z Sasami w 1073 r. Proponowało ono wspólne uderzenie na Saksonię i znaczne nabytki terytorialne (m.in. odzyskanie ziem straconych) ${ }^{82}$. Odpowiedź odmowną T. Grudziński potraktował jako niewątpliwy fakt istnienia sojuszu. Zatem między 1069 a 1073 r. miałby zostać zawarty nie tylko rozejm, ale także swego rodzaju sojusz - na bliżej nieznanych zasadach - skierowany przeciwko władcy Rzeszy. Inicjatorem tego miałby być Bolesław Szczodry, który nie chciał, aby Wieleci wbili Sasom przysłowiowy nóż w plecy ${ }^{83}$. Sama odmowa

79 T. Grudziński, Bolesław Szczodry..., s. 161.

80 T. Grudziński, Bolesław Śmiały-Szczodry..., s. 28.

81 N. Delestowicz, Bolestaw II Szczodry..., s. 140.

82 Lamperti Monachi Hersfeldensis Opera..., s. 163, pod rokiem 1073; Brunonis liber de bellosaxonico, ed. G.H. Pertz, MGH SS, t. 7, ed. idem, Hannoverae 1844, rozdz. 36, s. 341-342.

83 T. Grudziński, Stosunki polsko-wieleckie..., s. 496-497. 
wzięcia udziału w wojnie po stronie Henryka nie stanowi jeszcze żadnego dowodu. Wszakże był on takim samym wrogiem Słowian połabskich jak Sasi, a na dodatek osobiście wzią udział w wyprawie z 1069 r. ${ }^{84}$ Wybór pomiędzy Sasami i resztą Niemców był jedynie wyborem „mniejszego zła”, które nie mogło przekonywać Luciców. W grę musiało również wchodzić, rzeczywiście podkreślane przez historyków, wyczerpanie sił Związku, kilkukrotnie pokonanego i pozbawionego sporej części terytorium.

Sytuacja ta była jednak dużo bardziej skomplikowana, aniżeli przedstawił to T. Grudziński. W tym samym mniej więcej czasie Sasi wysunęli podobna propozycję do tej, z którą przybyli posłowie królewscy, co wywołało spory wśród elit wieleckich, a w efekcie nawet walki wśród starszyzny plemiennej, która się podzieliła na dwa obozy - zwolenników Sasów i popleczników Henryka IV ${ }^{85}$. W związku z tym nie mogli oni wykorzystać tej okazji i nie stanęli początkowo po żadnej stronie. Poza tym należy pamiętać, że - zgodnie z argumentami, jakie przekazali Henrykowi - byli bardzo wyczerpani wcześniejszymi walkami, a potencjał militarny spadł na tyle, iż nie byli w stanie podjać żadnych konkretnych akcji zbrojnych. Niezwykle trafnie scharakteryzował to J. Widajewicz w swoim krótkim opracowaniu kontaktów niemiecko-połabskich: „W czasie europejskiego sporu o inwestyturę mógł się związek dźwignąc $\mathrm{z}$ upadku, tymczasem niepojęta apatia ogarnęła jego członków; gdy Henryk IV zwracał się do nich z prośbą o pomoc, otrzymał odpowiedź, że ziemia, jaką posiadaja, zupełnie im wystarcza, i że są zadowoleni, gdy moga obronić granice swego państwa"86.

Pewne, aczkolwiek jedynie bardzo hipotetyczne światło moga rzucić przypuszczenia niemieckiego badacza Wolfganga Brüskego, który sugeruje, że w wyniku wspomnianej wojny domowej w Związku Lucickim z lat 50. XI w., do której wmieszali się Swen Estrydsen i Gotszalk obodrzycki, obok niektórych oderwanych plemion związkowych, pozostałe plemiona dostały się w zależność duńska, przez co król Danii miałby wpływ na politykę zagraniczna Wieletów ${ }^{87}$. Dobre kontakty między Księstwem Obodrzyckim

84 R.F.Barkowski, Stowianie połabscy..., s. 192.

85 Ibidem, s. 192-194.

86 J. Widajewicz, Niemcy wobec..., s. 28.

87 W. Brüske, Untersuchungen zur Geschichte des Liutitzenbundes. Deutsch-Wendische Beziehungen des 10.-12. Jahrhunderts, Münster-Köln 1955, s. 79; J. Sochacki, Stosunki publicznoprawne..., s. 128. 
i Dania, w połączeniu z zależnością Luciców od tego drugiego państwa, mogły się przyczynić do przymusowego braku zainteresowania walką z Sasami. Nie świadczy to jednak o współpracy ani sojuszu.

Uważam, że pogląd T. Grudzińskiego, jakoby sojusz sasko-wielecki miałby istnieć już około roku 1070, nie ma żadnych podstaw. Ponadto sa realne przesłanki świadczące o tym, że w 1073 r. Wieleci nie mieli wypracowanej jednej linii politycznej, a walki wewnętrzne związane $\mathrm{z}$ dwoma poselstwami dobitnie na to wskazuja. Zatem wówczas jeszcze nie mogło być mowy o jakimkolwiek porozumieniu, a jedynie narastający spór Sasów z Henrykiem uniemożliwił jednym i drugim akcje zbrojne i kontynuowanie podbojów na Połabiu.

Sojusz taki rzeczywiście został zawiązany, aczkolwiek jego geneza jest uchwytna źródłowo dopiero w 1075 r. Kronikarze wspominaja, że kiedy Bolesław Szczodry zobowiązywał się do wsparcia zbrojnego powstania saskiego, na dworze saskim znaleźli się także posłowie luciccy, którzy złożyli analogiczne jak władca polski zobowiąania ${ }^{88}$. Prawdopodobnie zatem stronnictwo popierające Sasów zwyciężyło wojnę domową i Wieleci postanowili mimo wszystko włączyć się otwarcie w sprawy wewnętrzne Rzeszy. Wydarzenia te należy jednak datować dopiero na wiosnę 1075 r. Propozycja zawiazzania sojuszu była już spóźniona, gdyż w czerwcu tegoż roku Henryk rozbił oddziały saskie w bitwie pod Homburgiem nad Unstruta, co równało się z porażką całego powstania ${ }^{89}$. Nie istnieją równocześnie żadne przesłanki, jakoby inspiratorem porozumienia miał być władca Polski, aczkolwiek mógł mieć na nie pośredni wpływ. Więcej raczej zależało od tego, której linii politycznej zwolennicy zwyciężyli wewnętrzne spory. Tak właśnie się przedstawia sytuacja porozumienia sasko-wieleckiego i domniemanego w nim udziału Bolesława Śmiałego. Powyższy wywód jednak nie wyczerpuje całego zagadnienia, gdyż należy jeszcze przyjrzeć się bliżej zaangażowaniu Polski w wojnę po stronie Sasów przeciwko królowi.

88 Lamperti Monachi Hersfeldensis Opera..., s. 214-215, pod rokiem 1075.

89 M. Becher, Die Auseinandersetzung Heinrichs IV. mit den Sachsen. Freiheitskampf oder Adelsrevolte? [w:] Vom Umbruch zu Erneuerung? - das 11. und beginnende 12. Jahrhundert - Positionen der Forschung, hrsg. v. J. Jarnut und M. Weinhoff, München 2006, s. 362; W. Czapliński, A. Galos, W. Korta, Historia Niemiec, Wrocław 2010, s. 118. 


\section{Polska a rebelia saska przeciwko Henrykowi IV}

Podobnie jak w wypadku Słowian należy nakreślić pokrótce tło wydarzeń, a więc omówić powody niezadowolenia Sasów, które popchnęły ich do sojuszu z księciem polskim i które były głównym bodźcem do tego, aby państwa Europy Środkowej (Polska, Węry), zależne do tej pory w mniejszym lub większym stopniu od Rzeszy, zdołały się spod jej wpływów wyswobodzić.

Początkiem konfliktu była próba zwiększenia władzy monarszej nad Saksonia, której pierwszym przejawem było wybudowanie na przełomie 1069/1070 r. warowni w paśmie górskim Harzu na pograniczu sasko-turyngskim. Kolejnym krokiem zmierzającym do realizacji tych planów było ograniczenie wpływów największego arystokraty z tego obszaru, księcia bawarskiego Ottona II z Norheimu, mającego także znaczne posiadłości w Saksonii ${ }^{90}$. Pozbawienie władzy Ottona nie zakończyło problemów w Saksonii, a jedynie je pogłębiło. Konflikt stopniowo narastał, a niezadowoleni możni skupiali się pod wodzą dwóch najważniejszych postaci: księcia saskiego Magnusa Billunga i biskupa Miśni Bennona, przy czym ten ostatni odgrywał wśród możnych rolę przewodnią ${ }^{91}$.

Jednakże spór ten nie sięgną jedynie elit i rycerstwa. Również wolni dotąd chłopi i ministeriałowie sascy poczuli się zagrożeni działaniami Henryka, gdyż próbował ograniczyć ich swobody. Postępujący proces feudalizacji sprawił, że oni również dołaczyli się do powstania, i co istotne, walczyli zdecydowanie dłużej aniżeli elity feudalne ${ }^{92}$.

Jak zatem w kontekście powyższych lakonicznych informacji wyglądały kontakty Bolesława z rebeliantami i kiedy mogły zostać zawiązane? Oprócz stałych kontaktów możnych saskich z księciem polskim (m.in. z poselstwami wymienianymi przez dwór krakowski i lüneburski), konkretne zobowiązania mogły być podjęte w 1071 r., w trakcie pobytu Bolesława Szczodrego w Miśni, gdzie został wezwany celem rozsądzenia sporu, jaki Polska toczyła z Czechami ${ }^{93}$. Miał tam doskonałą okazję do spotkania z przywódcami

90 W. Czapliński, A. Galos, W. Korta, Historia Niemiec..., s. 117-118.

91 G. Althoff, Heinrich IV., Darmstadt 2006, s. 87-88.

92 K. Tymieniecki, Dzieje Niemiec do poczqtku ery nowożytnej, Poznań 1948, s. 342-343; W. Czapliński, A. Galos, W. Korta, Historia Niemiec..., s. 118.

93 Pisze o tym bezpośrednio Lambert z Hersfeldu, aczkolwiek o tym konflikcie wspomina także Kosmas. 
opozycji saskiej. Tam też mogło powstać i być zatwierdzone wstępne porozumienie ${ }^{94}$.

O tym, że sojusz taki rzeczywiście został wówczas zawarty, świadczą - niestety - jedynie fakty pośrednie. W maju $1073 \mathrm{r}$. zarządzono wielką niemiecką wyprawę na Polskę, ponieważ Bolesław nie dotrzymał warunków mediacji z Miśni. Wyznaczono oficjalny termin na końcówkę sierpnia 1073 r. Sasi jednak nie chcieli brać udziału w tej wojnie i prosili Henryka o zwolnienie z obowiazku stawienia się w wyznaczonym miejscu, argumentując to zagrożeniem ze strony Wieletów ${ }^{95}$. Co prawda nie przedstawili wówczas jasno swojego stanowiska i nie było wiadomo, co dokładnie zamierzają zrobić, aczkolwiek nieco późniejsza odmowa udzielona królowi, jak również znaczne osłabienie Związku przez wcześniejsze najazdy i walki wewnętrzne, świadczą o tym, że zagrożenie to w istocie nie było wielkie. Wobec odmowy Henryka $^{96}$ Sasom nie pozostało nic innego, jak tylko rozpocząć powstanie ${ }^{97}$.

Pokrzyżowało to plany Niemcom, gdyż imperator musiał zmienić cel wyprawy i uderzyć na buntowników. Nie mamy jasnych dowodów, że było to działanie przeprowadzone w porozumieniu z Polska. Tadeusz Grudziński zauważa, że termin wybuchu powstania był szalenie niekorzystny dla Sasów, co świadczy o tym, że musieli uderzyć pod wpływem obustronnych ustaleń zawartych z Bolesławem Szczodrym ${ }^{98}$. Ciężko jednak całkowicie się z tym zgodzić. Henryk IV nakazał im stawić się w obozie wojskowym, który w dodatku znajdował się w Saksonii. W związku z tym musieliby wziąć udział w kampanii wojennej. Mogłaby ona zakończyć się niepomyślnie, zupełnie tak jak wyprawa Henryka IV na Wieletów sprzed kilku lat wcześniej, w trakcie której Otto z Norheimu został oskarżony o próbę zamachu stanu i została mu odebrana władza w Bawarii. Arystokraci sascy słusznie mogli się obawiać podobnego losu ${ }^{99}$.

94 T. Grudziński, Bolesław Szczodry..., s. 135.

95 Ibidem, s. 150; R. Kötzschke, H. Kretzschmar, Sächsiche Geschichte. Werden und Wandlungen eines Deutschen Stammes und seiner Heimat im Rahmen der Deutschen Geschichte, Bd. 1: Vor- und Frühgeschichte, Mittelalter und Reformationszeit, Dresden 1935, s. 58-64.

96 Brunonis liber de bello saxonico, ed. G.H. Pertz, MGH SS, Bd. 7, Hannoverae 1844 , cap. 23 , s. 336-337.

97 N. Delestowicz, Bolesław II Szczodry..., s. 150-151.

98 T. Grudziński, Bolesław Szczodry..., s. 150-157.

99 J.-H. Bartmuß, Deutschland von 919 bis zur Mitte des 11. Jahrhundert [w:] Deutsche Geschichte, Bd. 1: Von den Anfängen bis 1789, hrsg. v. idem, Berlin 
W każdym razie Bolesław Śmiały osiagnął swoje cele i uratował Polskę od najazdu niemieckiego. Odpowiedź na pytanie, czy rzeczywiście ratunek ten był elementem oficjalnych ustaleń, jest jednakże wattpliwa i prawdopodobnie był to efekt korzystnego dla Polski splotu wydarzeń niezależnych od poczynań polskiego monarchy.

Gdyby sojusz polsko-saski został zawiązany między 1071 a 1073 r., nie miałoby większego sensu poselstwo wysłane przez Śmiałego do Lüneburga w 1075 r., w którym Polacy obiecali pomoc przeciwko wszystkim wrogom Sasów, w szczególności zaś Henrykowi IV. Jak już wspomniałem, wówczas także na dwór księcia saskiego zawitali Wieleci z podobna propozycja. Gdyby zatem już wcześniej istniały jakieś oficjalne ustalenia, Bolesław nie musiałby obiecywać pomocy. Słusznie zauważył T. Grudziński, że prawdopodobnie nie było to pierwsze spotkanie i nie były pierwsze rozmowy ${ }^{100}$, jednakże nie możemy na tej podstawie wnioskować, że jakiekolwiek zobowiązania zostałyby zawarte wcześniej. Można sądzić, że gdyby Bolesław Szczodry wspomógł swoich sojuszników wcześniej, w momencie, gdy odwrócili uwagę Henryka od jego kraju, rebelia ta miałaby zupełnie inny przebieg. Po dwóch latach walk ich potencjał z pewnością spadł i obietnice polskie były spóźnione, co potwierdza tylko, że początkowo Polacy nie mieli zamiaru mieszać się w wewnętrzne sprawy Rzeszy. Poza tym również Sasi najprawdopodobniej nie traktowali poważnie polskich zobowiązań i traktowali je jako straszak na monarchę ${ }^{101}$.

Na podstawie powyższych rozważań trudno stwierdzić, że zawiązanie relacji z Sasami i Wieletami było elementem budowy trwalszego systemu politycznego zmierzającego do ograniczenia wpływów cesarstwa. Nic nie wskazuje na to, żeby Bolesławowi przyświecały początkowo takie cele. Co prawda obaj zachodni sojusznicy byli wrogami Henryka IV, aczkolwiek przymierze z nimi było raczej wyrazem potrzeby chwili i tego, że łączył ich z Polską wspólny wróg. Czy rzeczywiście władcy polskiemu zależało na trwałych relacjach - nie wiemy. Brak silniejszego zaangażowania w rebelię saską dowodzi, że był to raczej krótkotrwały alians bez szerokich planów i koncepcji politycznych.

1974, s. 274.

100 T. Grudziński, Stosunki polsko-wieleckie..., s. 490.

101 J. Sochacki, Stosunki publicznoprawne..., s. 129-130. 


\section{Polityka polska wobec Czech - książę Wratysław}

Czechy, mimo początkowo dość ścisłych relacji i współdziałania politycznego z Polska, od lat 80 . X w. pozostawały w stosunku do niej wrogie. Począwszy od schyłku rządów Mieszka I raz po raz wybuchały walki, z których najgroźniejszy był epizod z 1038/1039 r., kiedy to ksiązę Brzetysław wykorzystał załamanie się władzy centralnej w Polsce, złupił okrutnie - jak podają zgodnie Kosmas ${ }^{102}$ i Anonim zwany Gallem ${ }^{103}$ - ziemie polskie i zajął Ślask, pół wieku wcześniej zawojowany przez Mieszka $\mathrm{I}^{104}$. Kazimierz nazwany przez potomnych Odnowicielem długo nie był w stanie zmienić odziedziczonego stanu rzeczy, gdyż sytuację w kraju uspokoił dzięki pomocy rycerzy niemieckich, udzielonej za cenę hołdu lennego złożonego cesarzowi. Wykorzystał jednak niechęć cesarza do zbytniego wzrostu potęgi czeskiej i w $1050 \mathrm{r}$. zają sporne ziemie ${ }^{105}$. W świetle prawa zarówno Czesi, jak i Polacy podlegali Rzeszy, zatem władca czeski poprosił seniora o arbitraż. Niemcom zależało na utrzymaniu spokoju i stanu względnej równowagi na wschodnim pograniczu, hołdowali zatem zasadzie divide et impera. Ślask ostatecznie pozostał przy Polsce za cenę rocznego trybutu (1054). Władcy Czech nie zamierzali jednak dać za wygrana ${ }^{106}$. W takim momencie władzę obją Bolesław Szczodry.

102 Kosmasa Kronika Czechów, tłum. M. Wojciechowska, Wodzisław Śląski 2012, ks. 2, rozdz. 2, s. 112-113.

103 Anonim tzw. Gall, Kronika polska..., ks. 1, rozdz. 19, s. 41-42.

$104 \mathrm{O}$ tych wydarzeniach i mocno z nimi związaną rewolucją pogańską zob.: Z. Wojciechowski, W sprawie rewolucji pogańskiej w Polsce w 1037 r., „Życie i Myśl” 1950, t. 1, nr 7/8, s. 607-625; B. Krzemieńska, W sprawie chronologii wyprawy Brzetysława na Polskę, „Zeszyty Naukowe Uniwersytetu Łódzkiego, seria 1: Nauki Humanistyczno-Społeczne” 1959, z. 12, s. 23-37; R. Heck, O wtaściwa interpretacje najazdu Brzetysława na Polskę, „Ślaski Kwartalnik Historyczny Sobótka” 1966, t. 21, nr 2, s. 245-264; D. Borawska, Kryzys monarchii wczesnopiastowskiej w latach trzydziestych XI wieku, Warszawa 2013, zwłaszcza s. 147-148; B. Krzemieńska, Břetislav I. Čechy a střední Evropa w prvépolovině XI. století, Praha 1999, s. 188-229; M. Matla-Kozłowska, Pierwsi Przemyślidzi i ich państwo (od X do połowy XI wieku). Ekspansja terytorialna i jej polityczne uwarunkowania, Poznań 2008, s. 452-492.

105 M. Matla-Kozłowska, Pierwsi Przemyślidzi..., s. 361-365; S. Kętrzyński, Kazimierz Odnowiciel (1034-1058), Kraków 2010, s. 81; K. Dróżdż, Kazimierz Odnowiciel..., s. 110-111.

106 K. Dróżdż, Kazimierz Odnowiciel..., s. 112. 
Pierwszy zatarg z Czechami, mający jednak zdecydowanie głębsze - zdaniem badaczy - podłoże, wybuchł już w 1060 r., a więc w trzecim roku panowania Bolesława. Konflikt ten był zwiazany z - opisanymi już wcześniej - toczącymi się na Węgrzech walkami o władzę pomiędzy królem Andrzejem I a jego młodszym bratem Béla. Bolesław nie mógł osobiście wyruszyć na Węgry, gdzie armia niemiecką dowodził cesarz. Byłoby to jawne pogwałcenie przez polskiego monarchę prawa feudalnego. Postanowił jednak wykorzystać sposobność i „upiec dwie pieczenie na jednym ogniu”. Atakując Spitygniewa czeskiego, krewnego Andrzeja, blokował jego ewentualna wyprawę na Węgry, która zaprzepaściłaby szanse Béli na zwycięstwo. Gradec nie został zdobyty, ale strategicznie była to kampania wygrana, gdyż Czesi musieli zmienić plany i zamiast pomaszerować na Węgry, Spitygniew wolał bronić własnego państwa ${ }^{107}$. O walkach z Czechami wspomina Anonim Gall i prawdopodobnie można jego opis odnieść właśnie do tych wydarzeń. Kronikarz zanotował: „Albowiem gdy na początku swego panowania władał [Bolesław Śmiały - A.L.] zarówno nad Polakami, jak i Pomorzanami i zgromadził niezmierne ich mnóstwo w celu oblężenia grodu Gradec, to przez swój lekkomyślny upór nie tylko nie zdobył grodu, lecz [nadto] zaledwie uszedł z zasadzek czeskich i w ten sposób utracił panowanie nad Pomorzem"108. Zarówno H. Bulin, jak i L. Havlik wyrazili opinię, że było to związane $\mathrm{z}$ wciąż nie do końca ustalonymi granicami państwowymi między Polska a Czechami, a co za tym idzie z próbą rozszerzenia strefy własnych wpływów ${ }^{109}$.

Niedługo po tych wydarzeniach miało miejsce ciekawe i nie do końca zrozumiałe dla historyków wydarzenie. W styczniu 1061 r. zmarł Spitygniew i władzę zwierzchnią przeją jego młodszy brat Wratysław. Pod koniec 1062 r., jak podają źródła, doszło do zaskakującego mariażu pomiędzy Piastami i Przemyślidami. Książę czeski pojał za żonę siostrę Bolesława Śmiałego Świętosławę (czes. Swatawa) ${ }^{110}$. Było to pierwsze od czasów Mieszka I małżeństwo między przedstawicielami tych dwóch dynastii. Nie do końca wiadomo, co spowodowało zwrot w dotychczasowej polityce wzajemnej

107 G. Labuda, Zatargi..., s. 38-39.

108 Anonim tzw. Gall, Kronika polska..., ks. 1, rozdz. 22, s. 46.

109 L. Havlik et al., Slovanské Řiše ve střední Evropě a vzájemné vztahy českého státu do Konce 12. stol. [w:] Češi a Poláci v minulosti, t. 1, red. J. Macůrek, Praha 1964 , s. $49-50$.

110 Kosmasa Kronika Czechów..., ks. 2, rozdz. 20, pod rokiem 1061, s. 125. 
wrogości. Jak już wspomniałem, relacje polsko-czeskie - za wyjątkiem krótkiego okresu początków rządów Mieszka I - nie były nigdy dobre, a na dodatek dopiero zakończyły się walki o Gradec. Co prawda bardzo często wojna między dwoma państwami kończyła się mariażem potwierdzającym oficjalnie pokój, aczkolwiek zazwyczaj oznaczało to zwrot w polityce, a często także sojusz ${ }^{111}$.

Przywoływany już tu wielokrotnie T. Grudziński sądzi, że miało to znaczenie jedynie doraźne i nie tyle chodziło o stosunki z Polska, ile raczej z Węgrami i planowaną już wówczas wyprawą niemiecka, która miała obalić Bélę i osadzić na tronie wiernego Rzeszy Salomona. Związanie w ten sposób Czech z państwem polskim niosło za sobą neutralność Wratysława (krewnego Salomona) w ewentualnym konflikcie. Wniosek taki toruński badacz wyciagnął na podstawie milczenia źródeł - nie wiadomo nic o udziale księcia czeskiego w wojnie z 1063 r., prawdopodobnie więc nie wziął w niej bezpośredniego udziału. Nie powtórzyła się przy tym sytuacja z 1060 r., zatem musiał wówczas funkcjonować ów sojusz ${ }^{112}$. Teoria ta znalazła uznanie części badaczy ${ }^{113}$. Jeśli rzeczywiście chodziło Bolesławowi tylko o pomoc Węgrom, oznaczałoby to, że cel nie został osiagnięty, gdyż Béla zmarł tuż przed wkroczeniem wojsk niemieckich, a Géza nie potrafil opanować sytuacji.

W gruncie rzeczy nie wiemy, jak długo utrzymały się pokojowe stosunki z Czechami, gdyż nie dysponujemy żadnymi danymi źródłowymi między $1062 \mathrm{r}$. a początkiem lat $70 .{ }^{114}$ Jedyne informacje, które posiadamy, to obecność w Polsce juniora czeskiego, wyświęconego na księdza najmłodszego syna Brzetysława - Jaromira ${ }^{115}$. Norbert Delestowicz sądzi, że pobyt Jaromira w Polsce wcale nie był dla niego korzystny i przez długi czas jego osoba nie była przedmiotem sporu politycznego między władca Czech i Polski ${ }^{116}$. Co prawda władca polski mógł go traktować jako swego rodzaju element nacisku, niemniej jednak nie mamy żadnych informacji,

111 Tak było choćby w wypadku omówionego już w niniejszym artykule małżeństwa Salomona z córką Henryka Judyta, zob. s. 4-5.

112 T. Grudziński, Bolesław Szczodry..., s. 69-72.

113 A. Paner, Przemyślidzi. Od Borzywoja I do Przemysła Ottokara II. Ludzie $i$ wydarzenia w latach 872-1268, Gdańsk 2008, s. 109-110.

114 N. Delestowicz, Bolesław II Szczodry..., s. 71-72.

115 V. Novotný, Českédějiny, t. 1, cz. 2: Od Břetislava I. do Přemysla I., Praha 1913, s. 115 et seg.

116 Ibidem, s. 71-72. 
jakoby miał rzeczywiście wywierać presję na Wratysławie. Stanowi to dowód, że nawet jeśli polityka Polski i Czech nie szła jednym torem, to przynajmniej nie była całkowicie przeciwstawna, trwał więc najprawdopodobniej stan neutralny, który w każdej chwili mógł być naruszony. Jednakże obecność czeskiego pretendenta do władzy na dworze polskim mogła świadczyć o nienajlepszych stosunkach z Wratysławem. Podobna sytuacja, kiedy to przedstawiciel sasiedniej dynastii przebywał na dworze polskim i nie mógł przy tym liczyć na konkretną pomoc, miał miejsce za rządów Bolesława III Krzywoustego. Gościł on brata Kolomana Uczonego, aczkolwiek Anonim zwany Gallem wyraźnie stwierdził, że wynikało to jedynie z obowiązku gościnności ${ }^{117}$.

Wyłomem w relacjach polsko-czeskich mogło być dopiero wmieszanie się Jaromira w sprawy biskupstwa praskiego i wybranie go po śmierci Sewera w 1067 r. na biskupa. Trudno dociec, czy Bolesław realnie pomógł Jaromirowi - jak twierdzą niektórzy badacze $^{118}$. Jednakże od tej pory wzajemne stosunki się pogorszyły i w efekcie doszło do konfliktu, który przybrał formę wojny pogranicznej i wzajemnych wypraw łupieżczych. Wydarzenia te sa datowane na przełom lat 60. i 70 .

Bezpośrednią wzmiankę na temat stosunków polsko-czeskich mamy dopiero odnośnie do roku 1071. Lambert z Hersfeldu zanotował, że Bolesław i Wratysław zostali wezwani na sąd do Miśni, celem rozsądzenia sporu, jaki między nimi wybuchł. Mediacja seniora (zarówno Polska, jak i Czechy znajdowały się pod zwierzchnictwem Rzeszy, zatem Henryk miał prawo do rozsądzania sporów między nimi) nie przyniosła jednak efektu, gdyż Bolesław Szczodry, będąc już pewny swojej polityki, najechał ponownie ziemie Wratysława, co stanowiło zdaniem T. Grudzińskiego jawne pogwałcenie prawa lennego i czyniło Polskę państwem suwerennym ${ }^{119}$.

Stan wrogości utrzymał się w zasadzie do końca panowania Bolesława Śmiałego, co zaprzepaściło jakiekolwiek szanse na utworzenie sojuszu skierowanego przeciwko Henrykowi IV i powstanie bloku państw środkowoeuropejskich. Stan neutralności utrzymał się prawdopodobnie dosyć długo, niemniej jednak trudno

117 Anonim tzw. Gall, Kronika polska..., ks. 2, rozdz. 29, s. 92.

118 A. Paner, Przemyślidzi..., s. 111-112.

119 T. Grudziński, Bolesław Szczodry..., s. 150; idem, Bolesław Śmiaty-Szczodry..., s. 25; J. Žemlička, Čechy w době knížecí (1034-1198), Praha 1997, s. $100-101$. 
stwierdzić, czy Bolesław dążył do trwałego wciąnnięcia Czech $\mathrm{w}$ większy sojusz. Wratysław, zmuszony sytuacją wewnętrzna, nie mógł prowadzić innej polityki aniżeli proniemiecka i to w Henryku IV widział największego sojusznika i gwaranta utrzymania swej władzy. Niedługo później opłaciło się to mu wydatnie, gdyż król Rzeszy uhonorował go tytułem królewskim, obejmującym Czechy i Polskę, co znacznie wzmocniło jego pozycję zarówno w kraju, jak na arenie międzynarodowej. Nie wiadomo, czy zgodę na koronację uzyskałby od Grzegorza VII, zatem wydaje się, że to dzięki stałej wierności względem suwerena osiagnął takie wpływy i zaszczyty.

Zastanawiajace przy tym, aczkolwiek wykraczajace chronologicznie poza ramy niniejszego artykułu, jest również przyznanie w $1085 \mathrm{r}$. Wratysławowi tytułu króla. Miał on charakter wyłącznie indywidualny - dotyczył tylko tego władcy. Zgodnie z informacja podana przez Kosmasa w tytule obok Czech pojawiła się także Polska. Nie ulega wątpliwości, że sama koronacja stanowiła nagrodę za wieloletnią wierną służbę Henrykowi IV. Jedynie zastanawiające jest tu miejsce Polski. Gdyby rzeczywiście stała się wówczas zależna od Wratysława, spadłaby tym samym do rzędu państw lennych drugiego stopnia. Z perspektywy Bolesława Szczodrego jest jednak ważniejsze, czy geneza tego miała miejsce już w jego czasach.

\section{Podsumowanie i wnioski}

Ten krótki przegląd polityki wewnętrznej i zewnętrznej ludów sąsiadujących z Polska, ukazanej w kontekście aktywności politycznej Bolesława Szczodrego, nasuwa kilka wniosków. Są one w znacznej mierze sprzeczne z ustaleniami historiograficznymi. Oczywiście, w żadnym wypadku nie można moich rozważań traktować jako pewnych i pozbawionych jakichkolwiek błędów, niemniej jednak zarysowałem politykę wszystkich ludów z Europy Środkowej w miarę szczegółowo - na tyle, na ile pozwalają na to źródła. Niektóre pomijane dotąd wątki starałem się ukazać na szerszym tle i bardziej precyzyjnie aniżeli wcześniejsi badacze, a wnioski przeze mnie sformułowane odbiegają w pewnych miejscach od tych powszechnie przyjętych w historiografii tez i poglądów.

Celem badań była ocena, czy Bolesław był władca dążacym do zbudowania trwałego systemu politycznego w Europie Środkowej, dla wspólnej obrony przeciwko planom Henryka IV 
dotyczącym procesu uzależniania sąsiednich królestw i księstw środkowoeuropejskich (Węgry, Czechy, Polska, Słowiańszczyzna połabska). Jednakże dogłębna analiza wydarzeń w każdym z wyżej wymienionych państw i poszukiwanie w nich polskich inspiracji i wpływów prowadzi do wniosku, że władca polski nie dążył do budowy żadnego trwałego sojuszu, a większość jego działań miała charakter koniunkturalny, wynikajacy z aktualnych uwarunkowań politycznych. Obserwujemy to szczególnie w wypadku sojuszu z Saksonią i Wieletami. Obraz taki z pewnością opiera się na ustaleniach głównego badacza tego zagadnienia - profesora Tadeusza Grudzińskiego - który usiłował udowadniać nadzwyczajne talenty polskiego władcy i jego dalekowzroczna politykę. Wiele przesłanek pośrednich bądź czasem nawet ciszę źródłowa traktował jako argumenty potwierdzające jego teorię, stąd też niejednokrotnie kontrowersyjne, odbiegające od faktów źródłowych wnioski.

Badania prowadzone przez slawistów i germanistów każą nam zmienić nieco punkt widzenia i spojrzeć na tę kwestię $\mathrm{z}$ innej perspektywy. Nie ma żadnych realnych dowodów na polskie pośrednictwo w kwestii porozumienia sasko-wieleckiego, wręcz przeciwnie - dziejopisowie wspominają wojnę domową w Związku Lucickim, o której nawet słowem nie wspomniał T. Grudziński, a która ma tu zasadnicze znaczenie.

Sasi również nie mogli początkowo liczyć na pomoc ze strony księcia polskiego, a pogląd, jakoby termin wybuchu powstania miał być ściśle ustalony z dworem polskim, należy włożyć między bajki. Wynikało to tylko i wyłącznie z ich racji stanu, gdyz Henryk IV był doskonale zorientowany w sytuacji panującej na tym obszarze. Co prawda rozmowy z panami saskimi Bolesław mógł toczyć już w 1071 r., a nawet na długo przed tą data, niemniej jednak poselstwo z roku 1075 jest wyraźnym dowodem na to, że dopiero po dwóch latach otwartej wojny domowej książę polski postanowił włączyć się czynnie w walki w Saksonii. Być może poczuł się już na tyle pewnie, że był w stanie ostatecznie zerwać z Niemcami i uniezależnić się od Rzeczy. Zdaje się to potwierdzać koronacja, która miała miejsce rok później, w 1076 r. Trójporozumienie polsko-sasko-wieleckie rzeczywiście doszło do skutku, ale było już wówczas zbyt późno na jakiekolwiek konkretne działania, dzięki którym Saksonia mogłaby uzyskać niepodległość i działać wspólnie z Polska przeciwko Henrykowi IV i Rzeszy. 
Kwestia Czech jest niezwykle skomplikowana i ciężko stwierdzić, jak dokładnie kształtowały się relacje polsko-czeskie. Nie pomaga tu ubóstwo źródeł i nieliczne wzmianki polskie (Anonim zwany Gallem), czeskie (Kosmas) i niemieckie (głównie Lambert z Hersfeldu). Gruntowne badania Norberta Delestowicza wykazały, że zagadnienie to może nie być tak klarowne, jak do tej pory się nam wydawało. W gruncie rzeczy nie jesteśmy w stanie ustalić, na ile znaczące było małżeństwo Wratysława ze Świętosławą i czy miało głębsze, aniżeli pisze o tym T. Grudziński, konsekwencje. Możliwe, że początkowo rzeczywiście udało się wciagnąć księcia czeskiego do koalicji antycesarskiej, niemniej jednak jego późniejsze zatargi z juniorami zbliżyły go do swego seniora, a walki z Polska w 1070 i 1072 r. nie mogły poprawić niekorzystnej sytuacji. Nie pomogły nawet silne naciski papieża Grzegorza VII. Dlatego też próby te należy uznać jako incydentalne i nie można w niej widzieć trwalszych i głębszych zamierzeń politycznych.

Zupełnie inaczej na powyższym tle przedstawia się sytuacja Węgier. Od samego początku widać niezwykłą troskę księcia polskiego o to, żeby Węgry były niezależne albo chociażby nie ulegały zbyt silnie wpływom niemieckim. Wszelkie odwrócenie układu sił, a więc wzmocnienie się stronnictwa proniemieckiego, budziło niepokój po stronie polskiej. Co prawda Bolesław unikał bezpośredniego zaangażowania się w sprawy węgierskie, gdyż nie pozwalało mu na to wiele czynników. Zawsze jednak, gdy zachodziła taka potrzeba, udzielał wsparcia zbrojnego (Béli w $1060 \mathrm{r}$. i Gézie w 1063 r.), niemal natychmiast po wygnaniu przychylnych mu władców.

Istotna jest również postawa Bolesława względem sporu Gézy z papieżem Grzegorzem VII. Nie wspomniałem o tym, gdyż nie było to związane $\mathrm{z}$ wydarzeniami politycznymi, na których badaniu się skupiłem. Być może to właśnie stałe poparcie udzielane królowi węgierskiemu miało decydujący wpływ na to, że utrzymał się on przy władzy i wygrał spór z papieżem.

Sojusz z Węgrami był przez cały okres rządów Bolesława Szczodrego osia jego polityki. Wykorzystując swoich krewnych aspirujących do władzy nad Koroną Świętego Stefana, usiłował stworzyć przeciwwagę dla wpływów niemieckich.

Podsumowując, jedynie sojusz z południowym sassiadem wykazuje znamiona stałości i widać wyraźnie, że jedynie w tym wypadku książę polski dążył do utrzymania na Węgrzech władzy 
nastawionej wrogo do Rzeszy. Pozostałe związi polityczne stanowiły raczej efekt korzystnej sytuacji i nie były w żadnym stopniu zaplanowane przez polskiego władcę. Możliwe, że wraz z rozwojem wypadków koncepcja taka dojrzewała i Śmiały w 1075 r. rzeczywiście zaczą myśleć o ściślejszym związku, niemniej jednak więcej przesłanek wskazuje, że Saksonia nie była dla polskiego monarchy obszarem ważnym strategicznie. Tak więc odpowiadajac na pytanie postawione $\mathrm{w}$ tytule niniejszego artykułu, muszę wyraźnie stwierdzić, że nie można mówić o Bolesławie Szczodrym jako twórcy trwałego sojuszu skierowanego przeciwko Rzeszy i Cesarstwu. Tak szeroka koncepcja prawdopodobnie nie pojawiła się w działaniach Śmiałego, a inni wrogowie Niemiec byli o tyle pomocni, o ile mogli korzystnie wpłynać na sytuację Polski w konkretnych sytuacjach politycznych.

\section{Abstract}

Bolesław Szczodry (1058-1079) - Builder of a Central-European Anti-imperial Block?

The article analyzes contacts between Bolesław Szczodry (1058-1079) and neighbouring states in Central Europe (Hungary, the Czech lands, the Lutician Federation, Saxony). The main emphasis is on the influence of those contacts on Polish-German relations. The article attempts to answer the question as to whether the alliances formed by the Polish ruler were a result of a more serious, far-reaching policy directed against the German ruler. In connection with this, each state is dealt with separately, and relations with it are viewed separately from the remainder. The effect of such an approach is the perception that the majority of the actions of Bolesław Szczodry were of an ad hoc nature, and not stricte directed against the Empire. Only the Polish-Hungarian alliance - although also not without certain controversial aspects - gives the appearance of a lasting alliance, one fundamental for Polish policy at that time. As a result, the answer to the question in the title is in the negative: Bolesław Szczodry did not form alliances with neghbouring states with the aim of weakening Germany and of building a more powerful coalition capable of defeating King Henry IV. 